析の發達した現状ではよりよき對象地域 を签易に他に求め得られる篇でもあらう が、著者 Loeb は更に Indonesia に關 する資料が多く和籣國內に行し、他國の 研究者にとつて充分の資料入手の困難を その理由つ一つに数へて居る。

本書によつて取扱はれて居る諸任圤は Batak, Minangkabau，西部諸島では Nias, Mentawei, Engano, 北部では Atjeh, Gajo, Alas, 南部では Lampong, 及び末開部族 Kubu, Orang, Mamag, Sakai, Akit 等々であり、乙れらの各章

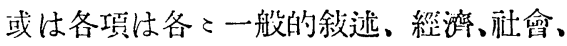
紫呚の各項に分たれて說朋されて居る。 從つて敘述はや」一面的に流れ易く、今 日の進んだ研究者にとつては或點粗野な 感じを抱かせられる梆ひはあるが、一航 には各人の好むとてろに・上り各處各項に ついて學的概觀を得易すい良畫である。

終りに饯せられて居る R. HEINEGelifern $の$ The Archaeology and Art は僅か30面の小論文ではあるが厢史 们に概能して石器時代から、Nias, Batak 等のそれを贋み、Hindu-Buddhist の時 代から Mohammedan 時代まで要領よ く悢めて居るが、彼の Sumatra 文化に

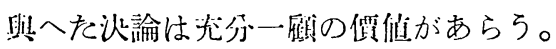

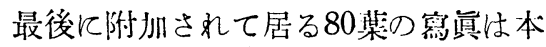
文之參浆して一段の僓值を昂めるもので ある。

向本書は Wien 大學比族學䂰究所編
"Wiener Beiträge zur Kulturgeschichte und Linguistik" の第 3 卷と して出版されて居る。(中野)

Hambly, W. D. : Culture Areas of Nigerin, Field Museum of Natural History, Anthropological Series. Vol. XXI, No. 3. 1935.

1929年よより30年に掛けて著者が主班之 なつて行つた西部アフリカの民笶學調柾 の報告の一部である。調椙の主眼は Nigeria 地方の文化の分布狀態の究朋に 嚚かれてるる樣である。

內谷は考古學などにも觸れてるるが、 此地で問題となる stone monumentき譄 製石器は木だ現任民之麼史的距係が付け られないとて闆單に付け、現在行つて みる手工業を中心とする物質文化と部族 生活の二つの方面に主力を注いでるる。

杫地方の文化圂は大别して北と阔との 二つに分けられる。手工篟中心の物質文 化に就て云方なら（i）北部文化圈は Sahara の方から垂直不綿織機器、革工. 罪 (持にサンダル型靴)、革暿、銀細工等 の文化嫳猄を受け入れてなる。(ii) 北部 文化国はマホメツト文化を受け入れて、 ラクダや馴を盛んに使ふ。(iii)北部文化 图では鈸冶が行なはれて居り、Sahara の南部一般に見られる。是に關係する信 仰と全く同じものが此處にもある。然し フイゴの型より見ると二つの型があり一 (35) 
オ゙は Sahara の型であるが今一つは Congo 地方のものに似てるる。てれに 對して南部文化图は（i）木製品を盛んに つくる。（ii）象牙彫刻が盛んである。 (iii)銅の䇺造が行なはれてるる等の特出 を持つ。乙れ等より見て著者は文化は大 體北部より流れて來たものであるが、 Sahara, 北部アフリカのみならす Congo 地方よりも入るもの川あるととを考へて 居る樣である。然しその主流をなすもの はマホメツト教の命令的文化の僖播であ るとしてわる。てれに細して南部の方は。 主として彼等の宗敉が北方より來る文化 倛播をさへぎつたと解してるる。木製品 の多いと云ふととはこの地方に不材が多 くあると云ふのみでなく、朴の面、朴像、 种殷の彫刻、宗㸚樂器等に於ける木彫に 粆する信仰から多く作られるのであると 斷じてるる。像牙の雕刻も同栐に象が居 ると云ふととのみでなく信仰と關係付け てみる。銅の鐓造は社會的、政治的事情 に依るものであるが此れにも亦宗教と關 係があると云ふ。

全體より·見て記述的部分が尠いが、過 去の文献はよく利明してある。ての地方 に關しては既に MEEK が The Northern Tribes of Nigeria, 2 vols. 1925; Tribal Studies in Northern Nigeria, 2 vols. 1931 を始め多くの調查記錄を發表 してみるのであるから、まとめて大觀し たと云ふ點で顀优あるものである。(杉浦)

\section{後藤守一・相川䣓雄 多零郡平井村白石稻}

荷山古墳 群馬橴史䠝名渗天然記念物調查

報呰 第 3 輯

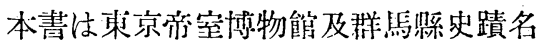
勝天然紀念物調查會が、昭和 8 年:10月。 協同發掘した群馬䅫多野郡平井村白石所 在稻條山古填に關する調䄳報告である。

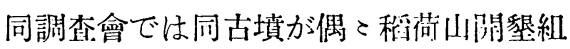
合の手により其後圓部一部より㘧輸及び 副葬品が發掘せられてより、之が縣內住 数の大古墳なること、叉出土遺物に二韭 家の埴輸、多量なる石製品等あるてとを 知り後藤守一・相川龍雄网氏に之が調查 方を啒託した。而して發掘には東京帝室 博物館の高橋直一氏も參加し、村民の援 助のもとに行はれたのである。調查後其 出土遺物は擧げて束京帝室博物館の有に 歸して其の代償金が村に交附されたが。 內千圓を本報告畫出版費として縣に寄附 した絬果之が出版を見たと云ふ。

本書は前編、後編に分かれ、前䌅には 調查事項を記载し、後編には狳恱と題し て考察が行はれてるる。

前編調查の部には第一に發掘の經過を 敘し、第二には稻嗬山古㥽の位造を述べ て、それが上照國の西南隅の橫谷一鏑川 谷一の中央に大平原に接せんとする部分 几位置し、鏑川谷が往昔の毛野開拓つ動 脉として上信を連䄈る線上にあることを 指摘し、附近飞散在する白石古㙋群》王 座を占めるものと見做す。第三には古墳 